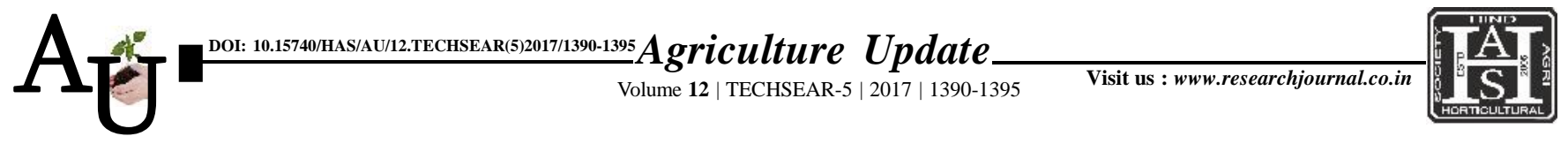

\title{
Research Article: Factors influencing extent of community participation of project and non project tank users in tank management
}

\author{
?. PRAShanth, M. JAGAN MOHAN REDDY, K. TIRUPATAiAh, I. \\ SREENIVASA RAO AND A. SRINIVAS
}

Article Chronicle:

Received :

15.07.2017;

Accepted :

30.07.2017

KEY WoRds:

Community participation, Tank users, Tan user group, Tank management
SUMMARY : : Community participation is critical to improve on-farm water management and crop productivity under the Tank Development programmes. This paper reports the factors which are influencing extent of community participation of project tank users of Andhra Pradesh Community based tank management project and non project tank users of both Telangna and Andhra Pradesh, in which, tank users participation through tank user groups was measured, and it was linked to various profile characteristics of the tank users. Multiple linear regression analysis reveals that adequate, timely and equitable availability ofwater is cardinal to ensure effective tank users participation in the community based tank management projects.positive and significant relationship between extent of community participation of project tank users in tank management and the variablesviz. education, farming experience, socio-political participation, extension contact, empathy, training received, scientific orientation, and decision making behaviour whereas positive and significant relationship between the extent of community participation of non-project tank users in tank management and the variables viz. education, farming experience, extension contact, empathy and decision making behavior. Whereas, farm size is negatively and significantly related with extent of community participation.

How to cite this article : Prashanth, P., Reddy, M. Jagan Mohan, Tirupataiah, K., Rao, I. Sreenivasa and Srinivas, A. (2017). Factors influencing extent of community participation of project and non project tank users in tank management. Agric. Update, 12(TECHSEAR-5) : 1390-1395; DOI: 10.15740/HAS/AU/ 12.TECHSEAR(5)2017/1390-1395.
Author for correspondence :

\section{P. PRASHANTH}

Department of Agriculture Extension, Agriculture College (PJTSAU), JAGTIAL (TELANGANA) INDIA

Email : prashanth897@ gmail.com

See end of the article for authors' affiliations 